\title{
UDC 664.643.1
}

\section{METHODS OF CALCULATION OF THE POWER FOR DOUGH KNEADING WITH THE USE OF BLADE-FREE WORKING PART}

\author{
Igor Stadnik $^{\mathbf{1}}$; Oksana Pylypets ${ }^{1}$; Mykhailo Pylypets ${ }^{1}$; \\ Volodymyr Poddubny ${ }^{2}$; Olena Kolomiiets ${ }^{3}$
}

\author{
${ }^{1}$ Ternopil Ivan Puluj National Technical University, Ternopil, Ukraine \\ ${ }^{2}$ Kyiv National University of Trade and Economics, Kyiv, Ukraine \\ ${ }^{3}$ Khmelnytsky Cooperative Trade and Economic Institute, \\ Khmelnytsky, Ukraine
}

\begin{abstract}
Summary. Baking industry plays one of the most important roles in the production of vital food products. The quality of the bakery products can be improved through the improvement of quality in technological process of dough kneading. A technical solution for providing greater contact with the environment, reducing the duration of the process, and, accordingly, increase productivity due to the developed design of a new machine with a cylindrical working body was proposed. The ways of regulating the course of the technological process in the working chamber of a new kneading machine are considered. They are based on the change of parameters: duration of kneading, temperature, humidity, rotation frequency of the working body. A method of calculating the required power based on the process of kneading the dough is proposed. It allowed obtaining a theoretical calculation of power consumption at unknown values of the friction forces action on the kneading drum, but the known frequency of its rotation with the corresponding design parameters and factors of influence. In addition, it makes possibility to determine the effort main components that affect to the power increase of the working body drive.
\end{abstract}

Key words: working part, non-Newtonian fluid, mixing, kneading, power, blade - free working part.

Statement of the problem. As it shows in the analysis of the current equipment and technologies in leading food producing companies there is a steady tendency to develop computer-operated technological machinery as well as integral technologies. It should be emphasised that working parts of the current machinery have permanent and unchangeable geometric shape. It is only the number of the drive shaft rotations that can be adjusted. It is quite obvious that such technical solutions do not bring any fundamental changes but make the kinematics of machine, its service and control more complicated.

However there are natural limitations which appear to be a significant obstacle in the further development in this field. They are connected to the speed of physico-chemical, biochemical and other processes in non-Newtonian fluids.

A number of technological processes of mixing are close to or have reached their boundaries. If we try to accelerate them through increasing work parameters and hence intensify the machine work this can result in significant decline in the quality of the product.

As follows from the short analysis of the state and features of the modern equipment as well as the methods of mixing of components there is still a problem of finding new trends in food engineering which will resolve the above mentioned problems either partially or in full.

During the mixing process all phenomena can be examined through the physicochemical properties which define the speed of the process on the molecular level and in local capacity of the machine work chamber which contains adequate number of inclusions from 
dispersed environment. Thus the study of the phenomena which takes place in the machine working chamber or in the individual stages of the process should be defined mainly by the hydrodynamic structure of the streams.

The use of different designs of working bodies and their reasonable use in mixing machines for non-Newtonian fluids is disclosed in the works of the authors $[1,2,3,4]$. They revealed the influence of working bodies on the environment with low frequencies in the implementation of complex modes of their interaction (superharmonic, polyphase, discrete, etc.). Studies of the dynamics of the environment in these machines are quite detailed $[5,6]$.

However, today there are new mixing technologies that require the implementation of complex modes of movement of the working body in terms of obtaining high quality products and minimal energy consumption. Therefore, the question of creating a discrete-pulse mode of influence of the working body with the presence of shock-vibration feature of the machine behavior in terms of interaction with a multicomponent environment is relevant. In part, these modes are disclosed by the authors [7] in a new design of the mixer for the paste and emulsions. In the process of production of biscuit semi-finished product, the prescription components undergo physical and chemical transformations, and interact with each other to form relationships, which leads to a change in the microstructure of the semi-finished product. In order to determine the mechanism of stabilization of the foam structure of sponge dough using extruded corn flour, the authors of [8] studied changes in the microstructure of sponge dough and finished sponge semi-finished product using a new mixer design.

One of the conditions for increasing the technological parameters and reducing the cost of production is to regulate the adhesive properties of the treated medium. The influence of adhesion on the technological process in the works of the authors is quite clearly and reasonably revealed $[7,9,10,11]$. With a special approach to the design of the working surfaces of the bladeless working body, it was possible to combine transport and technological functions. In order to model the process of mixing the components, the authors $[5,6,7,12]$ conduct in the mathematical description of the dynamics of the concentrated flour mixture and the dynamics of the two-phase layer, which forms a heterogeneous environment. In their works, they reveal the interaction of a heterogeneous environment with the surface of the working bodies and the working chamber.

From the analysis of the mentioned above works it is possible to realize qualitative technological process of mixing at the expense of geometrical designs of a working body and the chamber taking into account properties of the environment. Since the elastic and plastic dough has an anomalous viscosity, which varies depending on the shear stress, its properties and other factors, the surface phenomenon occurs at the boundary between two phases: the dough - one phase, the contact surface - the second phase $[13,14,15]$. Therefore, we proposed the geometry of the working bodies in the form of a cylindrical, conical, barrel-shaped, helical shape with a smooth or with different notches.

Analysis of the available investigations results. Current enterprises mostly use machines with the working parts which are shaped as a cylinder or conical spiral with the regular or changeable steps along the spiral length. The spiral mixes the components of the raw materials well both vertically and horizontally and plasticises them.

It was suggested to change the shape of the working chamber and working part which should increase the efficiency of the mixing components at the earlier stage (for example, nonNewtonian fluid dough) as well as its viscous environment. [1,2]. It is worth to mention that this is a new breakthrough in design of the working parts. A design of the new machine with cylinder working part is developed to ensure wider contact with the environment, reduce the duration of the process, and as a result to increase the efficiency (Figure 1). 

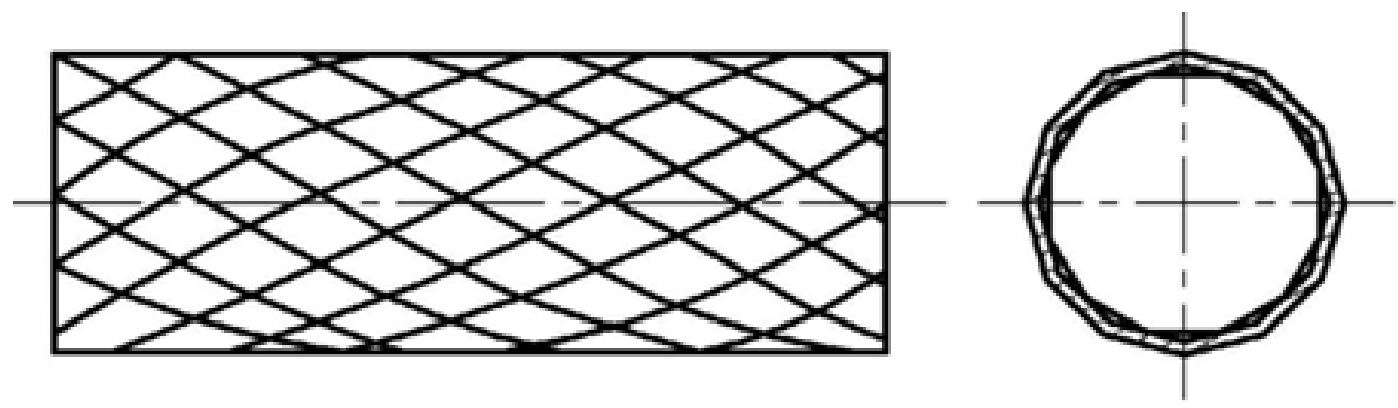

Figure 1. Cylinder working part with incisions

One of the problems that arises in the process of designing of new equipment for mixing viscous substances there is the one of prediction of final result as well as defining the quality of mixing while using the current «research technology». The choice of the working part is made by intuition which is followed by the experimental research tests to check if the choice was right. This is costly and results in a lot of energy and time consuming.

The objective of the work is to determine the required power of the working process of mixing the components.

Statement of the problem. Dough kneading machines can be classified as a complex system because they have the following features: structural complexity, functioning complexity, complexity in the choice of the behaviour in multi-alternative situations and development. Single and interactive run of the main processes in the working chamber of the machine is the serious factor that complicates the qualitative and quantitative assessment of the machine. The wide range of the raw material quality fluctuation affects substantially the run of the process and as a result, makes the process management more complicated. In order to prevent poor quality dough kneading and to achieve a good quality bread one can regulate the run of the processes in the working chamber of the dough kneading machine through the change of the parameters such as time of kneading, temperature, humidity, frequency of working part rotation.

The drum kneading part and polyhedral working chamber are main structural elements of the dough kneading machine $[1,2]$. Let us examine the major forces that act on the dough kneading drum. Every infinitely small element of the dough kneading drum area is affected by the friction forces of the dough. Those forces are generated as a result of action of the dough kneading drum on the component mixture which in its turn interacts with the surface of the working chamber during the whole process of dough kneading. The area with the large friction force is found on the first two stages of the kneading when the process of batching of the components is taking place. Under these conditions the friction force smoothly affects the kneading.

Thus the special feature in finding the affect of the friction force lies in the fact that we can propose the method to calculate the power for various conditions of interaction of the «product - kneading chamber» set. Our proposal is based on the comparison of the physical experiments and results of the corresponding numerous calculations. If you compare the corresponding results you can solve the so called «reverse» task that is you can find the friction ratio as well as asses the efficiency and expediency of using the particular material for designing the equipment.

When calculating the required power for the dough kneading in the blade-free machine and using the proposed methods there is a provisional distribution of the sections in the polyhedral working chamber. During the process of the kneading there are all stages with the unequivocal zones, while physical-mechanical properties of the made dough and the nature of action of the working part are different. 
The angular velocity of the kneading drum is the important feature of the kneading working process on the first stages of the dough kneading. Its optimal measurement is closely connected to the mixture friction ratio with internal surface of the polyhedral working chamber, loading coefficient, and friction with the cylinder surface of the kneading drum. Thus the angular velocity should be changeable which depends on the above parameters. Centrifugal mode prevents angular velocity of the kneading drum from increasing. In this mode the particles of the components mixture are moving only in the circular concentric paths, while the kneading is substituted by segregation because the particles with large mass tend to move to bigger diameter. When calculating the angular velocity (Figure 2) we can assume that when the angle of the mixture separation from the surface of the kneading drum is $35 \ldots 45^{\circ}$ the provision of frequency ratio is made:

$$
\omega=0.55 \omega_{C R}
$$

where $\omega_{C R}-$ being critical angular velocity which is calculated from the equation in the top point of the kneading drum of the centrifugal force $m \omega_{C R}^{2} \frac{D}{2}$ and weigh mg that is:

$$
m \omega_{C R}^{2} \frac{D}{2}=m \cdot g
$$

where $\mathrm{m}$ - being the weight of the particle.

Thus:

$$
\omega_{C R}=\sqrt{\frac{2 g}{D}}
$$

When we take this dependency into consideration the formula to calculate optimum angular velocity on the first stage of the components mixing will look as follows $(\mathrm{rad} / \mathrm{sec})$ :

$$
\omega_{C R}=\frac{2.1 \ldots 2.4}{\sqrt{D}}
$$

where $\mathrm{D}$ - being diameter of the cylinder part of the kneading drum, $\mathrm{m}$.

To calculate the power (Figure 2) we made certain assumptions: mixture;

1. cylinder part of the kneading drum contains $25-30 \%$ of the whole component diameter;

2. there is a correlation $1 / \mathrm{D} 2=0.8$ between the length of the cylinder part and its

3. the central angle of the section is $a=130 \ldots 140^{\circ}$. This is the angle of the intensive mixing of the components in the bottom part of the polyhedral working chamber. 


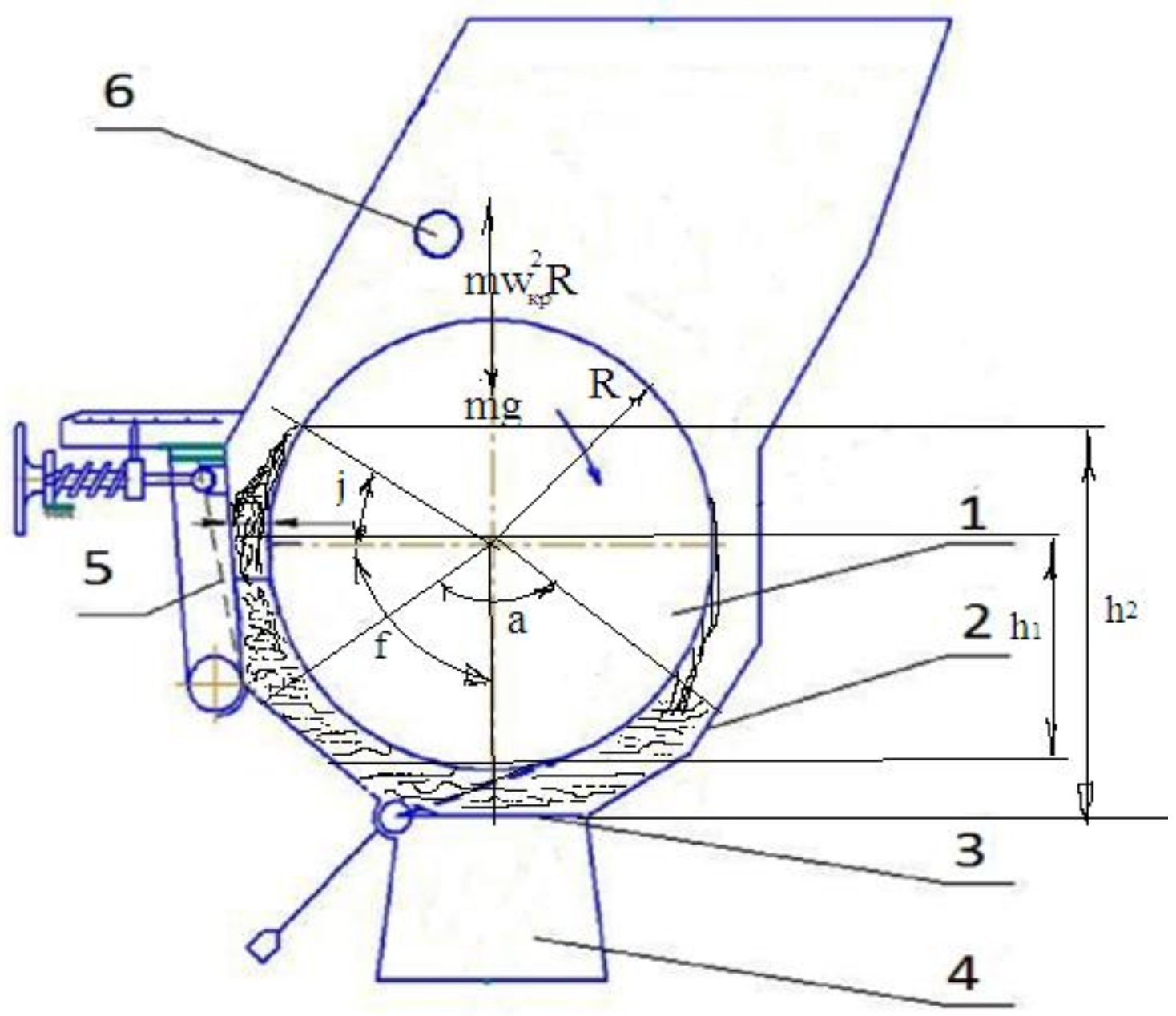

Figure 2. Diagram to define the parameters of the blade-free kneading: 1 - kneading drum; 2 - polyhedral working chamber; 3 - unloading gate; 4 - container for the made dough; 5 - passive vibration device; 6 - device for liquid components batching

Although approach seems to be very simple there are a lot questions in regards of the defining the actual movement of the components, the altitude they are lifted to and partial return into the «bath» under gravitation force.

Experiments proved $[20,21]$ that the mixture on its surface is lifted by the kneading drum as a result of adhesion as well as its friction with the surface of the kneading drum and working chamber. There are also some obstacles in accurate calculation of the mixture circulation. Due to the fact that the working chamber is a polyhedron and has not only cylinder parts but also conical ones in the plates joints [19] these obstacles can be overcome through the following estimations and calculations.

Let's assume that the power required to mix the components at the first stage of the kneading has two components such as lifting the mixture with the kneading drum Pk.d. and by the friction force Pf, Watt:

$$
P_{\text {mix }}=P_{k . d .}+P_{f}
$$

Friction in the working chamber of the machine has two components as well. The first component $P_{f}^{1}$ appears at the first minutes of the batching of the components and gradually 
reaches its maximum. The second force $P_{f}^{2}$ appears after 15-20c of the components batching. During the components kneading process an intensive mixing takes place at the bottom part «bath» of the working chamber and it has its own volume and it continuously supplies Pk.d. Power. As a result the friction force is as follows:

Thus:

$$
P_{f}=P_{f}^{1}+P_{f}^{2}=G_{2 h 1 z 2}+G_{3 h 2 z 3}
$$

$$
P_{\text {mix }}=P_{k . d .}+P_{f}=\left(G_{1} Z_{1}+G_{2} h_{1} \cdot Z_{2}+G_{3} h_{2 z 3}\right) \cdot n,
$$

where G1 - being weight of the mixture that is lifted by the kneading drum, H; G2 - being weight of the mixture that is lifted by the friction force in the «bath»; h1, h2 - height the mixture is lifted to by the kneading drum and friction accordingly; Z1, Z2, Z3 - number of circulations of the mixture per one revolution of the drum, due to the friction and number of circulations of the mixture in the «bath» per one revolution of the drum and friction force; $n$ - frequency of the drum revolutions, rev/sec.

We assume that the distribution of the mixture between G1, G2, G3 is in the following proportion in this type of machines:

$$
\begin{gathered}
G_{1}=0.35 \cdot G_{\text {total }} \\
G_{2}=0.25 \cdot G_{\text {total }} \\
G_{3}=0.40 \cdot G_{\text {total }}
\end{gathered}
$$

G1, G2, G3 mixture distribution are provisional quantities and they are continuously changing at the first stage of the kneading. The above mentioned distribution was defined after 30 seconds of the experimental batching of the components.

Thus G1 - weight of the components mixture that lies on the surface of the kneading drum.

G2 - weight of the components mixture that is lifted by the friction force. The given quantity in the further kneading process increases and in fact during the plasticization equals $100 \%$ that is it is equal to the amount of the prepared dough.

G3 - mixture distribution is the weight that is at the bottom part of the working chamber in the «bath». Its continuous supply with the components increases dough production which in its turn affects G1, G2 ratio. That is why it appears to be a supply of the G1, G2 for some time and defines the main factors of the homogeneity of the dough making.

We can calculate the height of lifting when we take into consideration the factors and parameters of the flow of the components. The height h1 can be calculated from the ratio (see picture 2)

$$
h_{1}=R(1+\sin j),
$$

where $\mathrm{R}$ - being radius of the kneading drum, $\mathrm{m} ; \mathrm{j}=45^{\circ}$ - being angle that equals to the friction angle of the mixture with the surface of the kneading drum at the given section. Then $h_{2}=$ $1,7 R$. 
Considering h1 height we assume that the angle of the lifting of the mixture by the friction force $f$ will be smaller than the angle of the friction $j$ and we take $f=90^{\circ}$ while taking into consideration the affect of the kneading drum. Then $\mathrm{h} 1=\mathrm{R}$. The number of circulation of the mixture both in the first and the second instance is equal $(Z 1=Z 2=2)$ based on the following assumptions:

$$
Z_{1}=\frac{t_{\text {rev }}}{t_{1}+t_{2}}
$$

where $t_{\text {rev }}=1 / n-$ time of one revolution of the kneading drum, c;

$t_{1}$ - being time for the mixture to be lifted by the kneading drum, c:

$$
t_{1}=\frac{90^{\circ}+j}{360^{\circ} n}=\frac{0.374}{n},
$$

where $\mathrm{t} 2$ - being time that equals to the falling of the mixture, $\mathrm{c}$ :

$$
t_{2}=\sqrt{\frac{2 h_{2}}{g}}=\sqrt{\frac{2 \cdot 1.7 R}{9.81}}=0.6 \sqrt{R},
$$

The number of the circulations $\mathrm{Z3}$ is defined if the time of the mixture falling equals to the time of its lifting, thus $Z_{2}=\frac{360^{\circ}}{2 \cdot f}=2$. Provided all conditions (2), assumptions $(3,4)$ and calculations are taken into consideration, the formula to calculate the power will look as follows:

$$
P_{\text {mix }}=P_{k . d .}+P_{f}=\left(G_{1} Z_{1}+G_{2} h_{1} \cdot Z_{2}+G_{3} h_{2 z 3}\right) \cdot n=0,35 \cdot G_{\text {total }} R n .
$$

Statistical analysis of the investigation. Theoretical calculation of the power consumption was made based on this approach. The measurements of the friction force with the kneading drum were unknown but the frequency of the kneading drum rotation with its size and factors that affect it were known. The following methods allow to measure the power needed for the kneading process in particular section. This allows to define the main forces that affect the increasing of the kneading drum drive power.

The data received from the solution (5) show that the calculation of the power consumption during the dough kneading can be explained through the fact that the increased number of the components in the working chamber causes significant power increase. The power and weight of the components in the working chamber have non-linear correlation. The greatest power change occurs at the end of the second stage prior plasticization with the maximal weight, that is when the dough is made and the gas phase is of $13.6 \%$. Using the above data we showed the correlation between the power and the weight of the components which are gradually fed into the working chamber of the machine (Figure 3). 


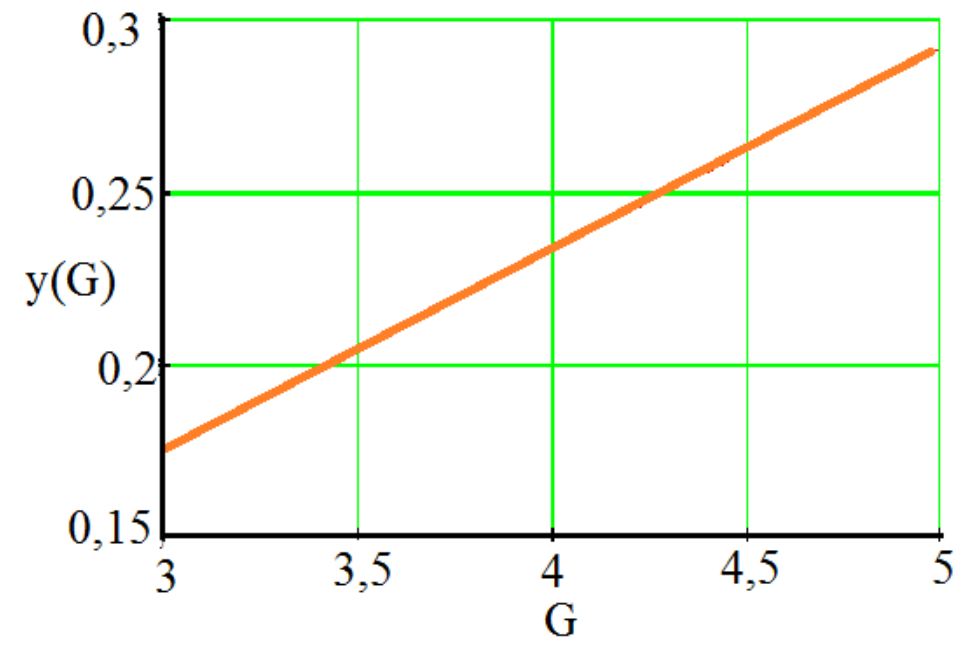

Figure 3. Correlation between the power and the dough weight during kneading n=1,2-1-:-1,7-1rot./c.

Figure 3 shows that the nature of the dough affects the power increase. The calculations proved that there is a significant increase in power during the first minutes of the dough kneading however in a short period of time it appears to be even and linear with the small increase in parameters provided the homogeneous mass is growing. This can be explained through the decrease in circulation and structural compound deformation which is caused by the shorter distance between the polymer molecules in the developing dough.

We learned $[4,5]$ that a range of methods are used to analyse the quality of the kneaded dough where analysis with consistographs and power balance being the most efficient. To support the received data in the process of dough kneading we can confirm that the curve is almost congruent with the consistograph of the wheat dough kneading.

Conclusions. The mixing power of the components mixture at the first stage of mixing is investigated in the paper. This power includes two components: lifting the mixture by the working body and the action of friction forces. Simultaneously, the friction force in the working chamber of the machine is considered in the form of two components. Theoretical calculation of power consumption at unknown values of friction forces on the working body by this method is obtained. In addition, the geometric and design parameters of the machine at a known speed of the working body with impact factors are used in the calculations.

This method allows to determine the required of power for the mixing process in a given section and makes it possible to determine the main components of the effort that affect the increase in the power of the drive of the working body.

\section{References}

1. Lisovenko O. T., Stadnyk I. Ya. A new way of kneading the dough. Scientific and practical conference "New technologies, equipment, safety and quality of food products: present and prospects" National University of Food Technologies. K.: NUHT, 2010. No. 10. P. 28.

2. Lisovenko O. T., Lisovenko I. O., Stadnyk I. Ya. Pat. 62460A Ukraine. Dough mixer. Application. 27.03.03; publ. 15.12.03, Bull. № 12. P. 2.

3. Pawel, D., Derkach, A., Stadnyk, I., Vitenko, T. (2016) Simulation of components mixing in order to determine rational parameters of working bodies. Advances in Science and Technology Research Journal. Vol. 9. P. 130-138. DOI: https://doi.org/10.12913/22998624/64068

4. Dolomakin Y. Simulation of liquid dough mixing in the machine with the rotor unit. Ukrainian Journal of Food Science. 2016. Volume 4. Issue 1. P. 120-130. ISSN 2310-1008.

5. Dolomakin Y., Babanov I., Shevchenko A., Babkina I. Influence of eccentricity of internal rotor's cylinder for mixing water-flour mixture on its kinematic and dynamic parameters. Scientific Letters of Academic Society of Michal Baludansky. Volume 5. Issue 4. 2017. P. 26-29. ISSN 1338-9432.

6. Szwedziaka K., Stadnykb I., Golyachukc S., Grzywaczd Ż. Justification of the rheological model of process 
of plastic material injection by the rollers. Agricul tural Engineering. 2019. Vol. 23. No. 3. P. $101-114$. ISSN 2083-1587. e-ISSN 2449-5999 DOI: https://doi.org/10.1515/agriceng-2019-0030

7. Stadnyk I., Pankiv Ju., Havrylko P., Karpyk H. Researching of the concentration distribution of soluble layers when mixed in the weight condition. Potravinarstvo Slovak Journal of Food Sciences. Vol. 13. 2019. No. 1. P. 581-592. DOI: https://doi.org/10.5219/1129

8. Lisovska T., Stadnik I., Piddubnyi V., Chorna N.. Effect of extruded corn flour on the stabilization of biscuit dough for the production of gluten-free biscuit. ukrainian food journal food engineering. Vol. 9. Issue 1. 2020. P. 159-174. ISSN 2304-974X (Print). ISSN 2313-5891. DOI: https://doi.org/10.24263/2304-974X-2020-9-1-14

9. Stadnyk I., Novak L., Matenchuk L. Global rheological approach to the quality of medium injected by the rollers. Potravinarstvo Slovak Journal of Food Sciences. Vol. 12. 2018. No. 1. P. 24-35. DOI: https://doi.org/10.5219/867

10. Stadnyk I., Piddubnyi V., Krsnozhon S., Antoshkova N. Influence of reduction on adhesive properties. Potravinarstvo Slovak Journal of Food Sciences. Vol. 14. 2019. P. 76-87. DOI: https://doi.org/10.5219/1195

11. Stadnyk I., Piddubnuy V., Eremeeva O., Karpyk H. Features of heat transfer in the environment when it is sprayed with rotary rollers. Potravinarstvo Slovak Journal of Food Sciences. Vol. 12. 2018. No. 1. P. 824-835. DOI: https://doi.org/10.5219/977

12. Stadnyk I., Hushtan T., Sabadosh G., Yevchuk Ya. Formation of microbial biofilms on stainless steel with different surface roughness. Potravinarstvo Slovak Journal of Food Sciences. Vol. 13. 2019. No. 1. P. 915-924. DOI: https://doi.org/10.5219/1190

13. Stadnyk I., Piddubnyi V., Karpyk H., Kravchenko M., Hidzhelitskyi V. Adhesion effect on environment process injection. Potravinarstvo Slovak Journal of Food Sciences. Vol. 13. 2019. No. 1. P. $429-437$. DOI: https://doi.org/10.5219/1078

14. Vitenko T., Stadnik I., Droździel P., Rudawska A. The substantiation of the optimal parameters for dough pinning-out rollers. Advances in Science and Technology Research Journal. Volume 14. Issue 1. 2020. P. 32-41. DOI: https://doi.org/10.12913/22998624/113611

15. Stadnyk I., Piddubnyi V., Krsnozhon S., Antoshkova N. Influence of reduction on adhesive properties. Potravinarstvo Slovak Journal of Food Sciences. Vol. 14. 2020. P. 76-87. DOI: https://doi.org/10.5219/1195

16. Stadnyk I., Kolomiiets O., Dziana O. Substantiation of foamy structure formation in a glutenfree biscuit. Potravinarstvo Slovak Journal of Food Sciences. Vol. 14. 2020. P. 1008-1019. DOI: https://doi.org/10.5219/1399

17. Piskunov S., Iasechko M., Minko N., Dolomakin Y. Taking into account the correlated errors of measurements when estimating parameters of object trajectory at mechanical movement. International Journal of Emerging Trends in Engineering Research. 2020. Volume 8. No. 9. P. 5603-5606. DOI: https://doi.org/10.30534/ijeter/2020/112892020

18. Dolomakin Y. Determination of the main stages of mixing wheat sourdough relative method. Journal of food and packaging science. Technique and Technologies. 2016. Year V. No. 9. P. 49-54. (ISSN: 13147773).

19. Stadnyk I. Ya. Scientific and technical bases of processes and development of equipment for blade - free dough kneading. Abstract of the doc. dissertation. 2013, 40 p.

20. Dobrotvor I. H., Stadnyk I. Ya. Investigation of the distribution of concentrations of soluble layers during mixing. Storage and processing of grain. 2011. No. 8. P. 48-50.

21. Stadnik I. Ya. Protsesi pershoYi stadIYi zamIshuvannya na novIy tIstomIsilnIy mashinI. VIsnik TDTU. № 2. T. 14. 2009. P. 72-79.

22. Stadnik I., Lyasota O., Poddubny V., Korets L. Peculiarities of heat exchange in dough under the rotating rollers action. Scientific Journal of TNTU. Tern.: TNTU, 2019. Vol. 95. No. 3. P. 75-85. (Manufacturing engineering and automated processes). DOI: https://doi.org/10.33108/visnyk_tntu2019.03.075

23. Mykhailyshyn R., Prots' Ya., Savkiv V. Optimization of bernoulli gripping device's orientation under the process of manipulations along direct trajectory. Scientific Journal of the Ternopil National Technical University. Tern.: TNTU. 2016. No. 1 (81). P. 107-117.

\section{Список використаної літератури}

1. Лісовенко О. Т., Стадник І. Я. Новий спосіб замішування тіста: науково-практична конференція «Новітні технології, обладнання, безпека та якість харчових продуктів:сього whereння та перспективи» Національний університет харчових технологій. К.: НУХТ, 2010. № 10. С. 28.

2. Тістомісильна машина: пат. 62460 А Україна; заявл. 27.03.03; опубл. 15.12.03, Бюл. № 12. 2. с.

3. Pawel, D., Derkach, A., Stadnyk, I., Vitenko, T. (2016) Simulation of components mixing in order to determine rational parameters of working bodies. Advances in Science and Technology Research Journal. Vol. 9. P. 130-138. DOI: https://doi.org/10.12913/22998624/64068 
4. Dolomakin Y. Simulation of liquid dough mixing in the machine with the rotor unit. Ukrainian Journal of Food Science. 2016. Volume 4. Issue 1. P. 120-130. ISSN 2310-1008.

5. Dolomakin Y., Babanov I., Shevchenko A., Babkina I. Influence of eccentricity of internal rotor's cylinder for mixing water-flour mixture on its kinematic and dynamic parameters. Scientific Letters of Academic Society of Michal Baludansky. Volume 5. Issue 4. 2017. P. 26-29. ISSN 1338-9432.

6. Szwedziaka K., Stadnykb I., Golyachukc S., Grzywaczd Ż. Justification of the rheological model of process of plastic material injection by the rollers. Agricul tural Engineering. 2019. Vol. 23. No. 3. P. 101-114. ISSN 2083-1587. e-ISSN 2449-5999 DOI: https://doi.org/10.1515/agriceng-2019-0030

7. Stadnyk I., Pankiv Ju., Havrylko P., Karpyk H. Researching of the concentration distribution of soluble layers when mixed in the weight condition. Potravinarstvo Slovak Journal of Food Sciences. Vol. 13. 2019. No. 1. P. 581-592. DOI: https://doi.org/10.5219/1129

8. Lisovska T., Stadnik I., Piddubnyi V., Chorna N.. Effect of extruded corn flour on the stabilization of biscuit dough for the production of gluten-free biscuit. ukrainian food journal food engineering. Vol. 9. Issue 1. 2020. P. 159-174. ISSN 2304-974X (Print). ISSN 2313-5891. DOI: https://doi.org/10.24263/2304-974X-2020-9-1-14

9. Stadnyk I., Novak L., Matenchuk L. Global rheological approach to the quality of medium injected by the rollers. Potravinarstvo Slovak Journal of Food Sciences. Vol. 12. 2018. No. 1. P. $24-35$. DOI: https://doi.org/10.5219/867

10. Stadnyk I., Piddubnyi V., Krsnozhon S., Antoshkova N. Influence of reduction on adhesive properties. Potravinarstvo Slovak Journal of Food Sciences. Vol. 14. 2019. P. $76-87$. DOI: https://doi.org/10.5219/1195

11. Stadnyk I., Piddubnuy V., Eremeeva O., Karpyk H. Features of heat transfer in the environment when it is sprayed with rotary rollers. Potravinarstvo Slovak Journal of Food Sciences. Vol. 12. 2018. No. 1. P. 824-835. DOI: https://doi.org/10.5219/977

12. Stadnyk I., Hushtan T., Sabadosh G., Yevchuk Ya. Formation of microbial biofilms on stainless steel with different surface roughness. Potravinarstvo Slovak Journal of Food Sciences. Vol. 13. 2019. No. 1. P. 915-924. DOI: https://doi.org/10.5219/1190

13. Stadnyk I., Piddubnyi V., Karpyk H., Kravchenko M., Hidzhelitskyi V. Adhesion effect on environment process injection. Potravinarstvo Slovak Journal of Food Sciences. Vol. 13. 2019. No. 1. P. $429-437$. DOI: https://doi.org/10.5219/1078

14. Vitenko T., Stadnik I., Droździel P., Rudawska A. The substantiation of the optimal parameters for dough pinning-out rollers. Advances in Science and Technology Research Journal. Volume 14. Issue 1. 2020. P. 32-41. DOI: https://doi.org/10.12913/22998624/113611

15. Stadnyk I., Piddubnyi V., Krsnozhon S., Antoshkova N. Influence of reduction on adhesive properties. Potravinarstvo Slovak Journal of Food Sciences. Vol. 14. 2020. P. 76-87. DOI: https://doi.org/10.5219/1195

16. Stadnyk I., Kolomiiets O., Dziana O. Substantiation of foamy structure formation in a glutenfree biscuit. Potravinarstvo Slovak Journal of Food Sciences. Vol. 14. 2020. P. 1008-1019. DOI: https://doi.org/10.5219/1399

17. Piskunov S., Iasechko M., Minko N., Dolomakin Y. Taking into account the correlated errors of measurements when estimating parameters of object trajectory at mechanical movement. International Journal of Emerging Trends in Engineering Research. 2020. Volume 8. No. 9. P. 5603-5606. DOI: https://doi.org/10.30534/ijeter/2020/112892020

18. Dolomakin Y. Determination of the main stages of mixing wheat sourdough relative method. Journal of food and packaging science. Technique and Technologies. 2016. Year V. No. 9. P. 49-54. (ISSN: 13147773).

19. Стадник I. Я. Науково-технічні основи процесів та розробка обладнання для безлопатевого замішування тіста: автореф. дис. ... док. дисертації. 2013 р., 40 с.

20. Добротвор I. Г., Стадник I. Я. Дослідження розподілу концентрацій розчинних шарів при змішуванні. Хранение и переработка зерна. 2011. № 8. С. 48-50.

21. Стадник І. Я. Процеси першої стадії замішування на новій тістомісильній машині. Вісник ТДТУ. № 2. T. 14. 2009. С. 72-79.

22. Stadnik I., Lyasota O., Poddubny V., Korets L. Peculiarities of heat exchange in dough under the rotating rollers action. Scientific Journal of TNTU. Tern.: TNTU, 2019. Vol. 95. No. 3. P. 75-85. (Manufacturing engineering and automated processes). DOI: https://doi.org/10.33108/visnyk_tntu2019.03.075

23. Mykhailyshyn R., Prots' Ya., Savkiv V. Optimization of bernoulli gripping device's orientation under the process of manipulations along direct trajectory. Scientific Journal of the Ternopil National Technical University. Tern.: TNTU. 2016. No. 1 (81). P. 107-117. 
УДК 664.643.1

\title{
МЕТОДИКА РОЗРАХУНКУ НЕОБХІДНОЇ ПОТУЖНОСТІ ПРИ ЗАМІШУВАННІ ТІСТА БЕЗЛОПАТЕВИМ РОБОЧИМ ОРГАНОМ
}

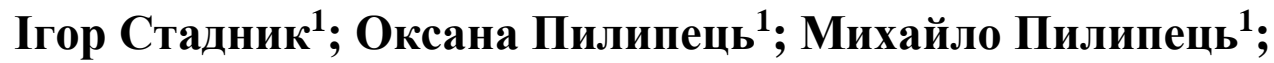 Володимир Піддубний ${ }^{2}$ Олена Коломієць ${ }^{3}$}

\author{
${ }^{1}$ Тернопільський національний технічний університет імені Івана Пулюя, \\ Тернопіль, Україна \\ ${ }^{2}$ Київський національний торговельно-економічний університет, \\ Київ, Украӥна \\ ${ }^{3}$ Хмельницький кооперативний торговельно-економічний інститут, \\ Хмельницький, Україна
}

\begin{abstract}
Резюме. Одне із важливих місиь у виробництві життєво потрібних харчових продуктів займає хлібопекарська галузь. Поліпшення якості хлібобулочних виробів можна досягти за рахунок підвищення якості технологічного процесу замішування тіста. Створення нової конструкиії починається з використання елементів геометричного моделювання поверхні, щзо впливає на результати технологічного процесу. Запропоновано технічне вирішення із забезпечення більшого контакту з середовищем, зменшенням тривалості процесу, $i$, відповідно, збільшенням продуктивності за рахунок розробленої конструкції нової машини з циліндричним робочим органом. Розглянуто шляхи регулювання перебігу технологічного процесу в робочій камері нової тістомісильної машини, щчо трунтуються на зміні параметрів: тривалості замішування, температури, вологості, частоти обертання робочого органу. Проаналізовано конструкиію ичліндричного робочого органу та фактори впливу його конструктивних особливостей на ефективність процесу змімування компонентів та якісного транспортування на третій стадії тістоутворення. На основі розгляду процесу замішування тіста запропоновано методику розрахунку необхідної потужності. Запропонована методика дозволила отримати теоретичний розрахунок обчислення затрат потужності при невідомих значеннях дї сил тертя на місильний барабан, але відомій частоті його обертання 3 відповідними конструктивними параметрами та факторами впливу. Крім иьього, дає можливість з'ясувати основні складові зусилля, щчо впливають на збільшення потужності привода робочого органу. За рахунок наведених залежностей виконано розрахунок визначення необхідної потужності при дії в'язкого тертя та наведено визначення основних складових утворюючого тіста, щзо трунтуються на вирішенні завдання переміщення його маси в орієнтуючих каналах по обмежених кругових направляючих.
\end{abstract}

Ключові слова: робочий орган, неньютонівська рідина, перемішування, замішування, потужність, безлопатевий робочий орган.

Отримано 26.09.2020 